\title{
RESEARCH
}

Open Access

\section{Coastal flood risk: improving operational response, a case study on the municipality of Leucate, Languedoc, France}

Paul Durand ${ }^{1,2}$, Brice Anselme ${ }^{1,3^{*}}$ (D), Stéphanie Defossez ${ }^{4,5}$, Sylvain Elineau ${ }^{2,6}$, Monique Gherardi $^{4,5}$, Lydie Goeldner-Gianella ${ }^{1,2}$, Esméralda Longépée ${ }^{7,8}$ and Alexandre Nicolae-Lerma ${ }^{6}$

\begin{abstract}
Background: Climate change and rising sea level will certainly lead to significant changes in the management of low-lying coastal areas in the coming decades. While the most recent studies in the field of coastal storms-related flooding are increasingly integrated, simultaneously addressing hazards and vulnerability, as well as population risk perception, there is still little work to consider the preparedness of stakeholders to manage crises whose frequency and intensity are likely to increase in the next years.

Methods: The aim of this paper is to expose the major results of the CRISSIS research program, which proposed a multi-disciplinary approach to the management of coastal flood risk in a town particularly exposed on the French Mediterranean coast. The originality of the project was to offer both an integrated approach to risk by analysing its 3 dimensions (hazard, impact and vulnerability, and representations and perceptions held by populations and stakeholders, or « risk culture ») and a very operational section focused on the evaluation of crisis management measures led by local stakeholders. To achieve this objective, two crisis exercises were organized, the first one to test the assimilation by the municipality staff of existing crisis management procedures and the second to allow local actors to integrate in their crisis management procedures the new risk knowledge data issued from research conducted under the program.
\end{abstract}

Results: The project has had three main features; (i) it accurately mapped the submersible areas that present a critical vulnerability, both material and human; (ii) it revelated the poor social representation of marine submersion risk, as well as the obvious lack of awareness of crisis management systems and tools and the behavior to adopt in the event of flooding; (iii) Finally, it highlighted the need, through the crisis exercises, for a better assimilation by the municipality staff of the crisis management procedures defined in the Municipal Rescue Plan.

Conclusion: The CRISSIS project has demonstrated the usefulness of an integrated and operational approach of coastal flood risk, not only in terms of studying hazards, stakes and vulnerability, but also in terms of crisis management, in particular through the organisation of crisis simulation exercises.

Keywords: Coastal flood risk, Numerical modeling, Vulnerability, Risk perception, Crisis exercise, Leucate

\footnotetext{
* Correspondence: brice.anselme@univ-paris1.fr

${ }^{1}$ Université Paris 1 Panthéon-Sorbonne, 191 rue Saint Jacques, F-75005 Paris,

France

${ }^{3}$ Pôle de Recherche pour l'Organisation et la Diffusion de I'Information

Géographique, UMR 85862 rue Valette, F-75005 Paris, France

Full list of author information is available at the end of the article
} 


\section{Background}

With global warming causing a rise of sea levels, the vulnerability of coastal towns to flooding risk during storms has increased. This issue is bound to become a key element in the management of low coastlines in decades to come, and multiple studies have been published on this subject in recent years (Cariolet et al. 2012. Vinet et al., 2012; Hurlimann and al., 2014; Duan et al. 2014 and Duan et al. 2015; King and al., 2014; Rulleau et al., 2015). While earlier studies were often relatively segmented, focusing either on the hazard itself or on impact and vulnerability, more recent research programs on the topic have been much more integrated, simultaneously addressing hazards and vulnerability, as well as the population's perception of risk - see for instance the French programs MISEEVA (2008-2011), JOHANNA (2010-2013), BARCASUB (2010-2013), COCORISCO (2011-2014), and European studies on the management of marine flooding and submersion risk (Samuels et al. 2008; Sorensen et al. 2017).

The two-year CRISSIS program (Characterizing Submersion Risks in Sensitive Sites), launched in 2015 in a coastal town of the French region of Languedoc (municipality of Leucate), falls under this last category: through a multi-disciplinary approach associating geographers, modelers, GIS specialists and crisis and risk management experts, the project offers an integrated perspective on coastal flooding by exploring this risk's three dimensions in coastal areas (hazard; impact and vulnerability; and representations and perceptions held by populations and stakeholders, or « risk culture »). This study does however stand out from other literature, in that it also includes a very operational section focusing on the evaluation of crisis management measures led by local stakeholders - an aspect that has rarely considered by research programs so far.

The preparedness of stakeholders to manage crises whose frequency and intensity is likely to increase is a key element in the management of vulnerable coastal spaces. Several studies have shown that the damages caused by recent disasters in coastal areas have been aggravated by the local authorities' lack of preparedness (Daniels et al. 2011; Genovese et al. 2011; Genovese and Przyluski 2013). It is not enough to know and prevent risk: we also need to be prepared to manage the resulting crises (Lagadec 1993, 2001, 2004, 2012; Egli 2013). In this perspective, the CRISSIS project aims to help local stakeholders use the new findings produced through the analysis of the three dimensions of risk. Two crisis management exercises were thus organized from the outset: one took place halfway through the project to test the uptake of crisis management procedures ("Plan Communal de Sauvegarde" (PCS), or « Municipal Rescue Plan ») by local authority staff; a second more ambitious test took place at the end of the program, with the objective of testing the PCS again but this time by integrating new data produced as part of the program's findings. Overall, the objective of CRISSIS has been to both generate new knowledge to improve risk prevention and help optimize crisis management by local stakeholders by facilitating the prioritization and classification of actions in the event of a flood. After a brief introduction of its study area, this paper will describe the methodology that guided its operational approach to coastal flood risk, before presenting its key findings.

\section{Study area}

The area chosen for this study is the municipality of Leucate, a town located on the French coastline of the Languedoc region. The municipality comprises of four seaside resorts located on both sides of the Leucate cape. These include from South to North: the resort of Port Leucate, built in the seventies as part of the Racine development scheme, on the coastal strip that cuts across the Salses-Leucate lake; the nudist village located on the narrowest part of the strip; Leucate Plage, at the foot of the cape's southernmost cliff; and La Franqui, at the foot of the cape's northern cliff. The area is affected by large-scale urban and touristic issues, as the town is densely populated during the summer season, growing from 5000 year-round residents to almost 100,000 during the high season. The urban areas of Port Leucate and Leucate Plage are also very exposed to coastal flood hazards, and in particular Port Leucate which was built on a strip of low altitude coastal land (for the most part under $3 \mathrm{~m} \mathrm{NGF).} \mathrm{Both} \mathrm{areas} \mathrm{are} \mathrm{periodically} \mathrm{flooded}$ when strong south-eastern storms occur (Ullmann 2009), during which the waves can cause the sea level to rise to up to $3 \mathrm{~m} \mathrm{NGF}$ (Anselme et al. 2011). The floods can also be aggravated by a combination of wind and heavy rainfall, causing the lake's level to rise and provoking major runoff down the cliffs of the cape (Fig. 1).

Paradoxically, in spite of its high vulnerability to risk (the state of natural disaster has been declared 14 times in the area since 1982, including 13 times for "flood/submersion" events, GASPAR database of the French Ministry of Ecological Transition, http://www.georisques.gouv.fr/ acces-aux-donnees-gaspar), the town of Leucate has been relatively slow in applying risk regulation measures in comparison with other municipalities located on the Languedoc-Roussillon coastline. According to a recent publication of the Department of Planning and Housing of the Rhône-Mediterranean basin (DREAL Rhône-Méditerranée 2016), the first PPRI ("Plan de Prévention des Risques Inondation", or "Flood Risk Prevention Plan") was only adopted in November 2012, while all the other municipality in the region subject to marine submersion risk had already had 


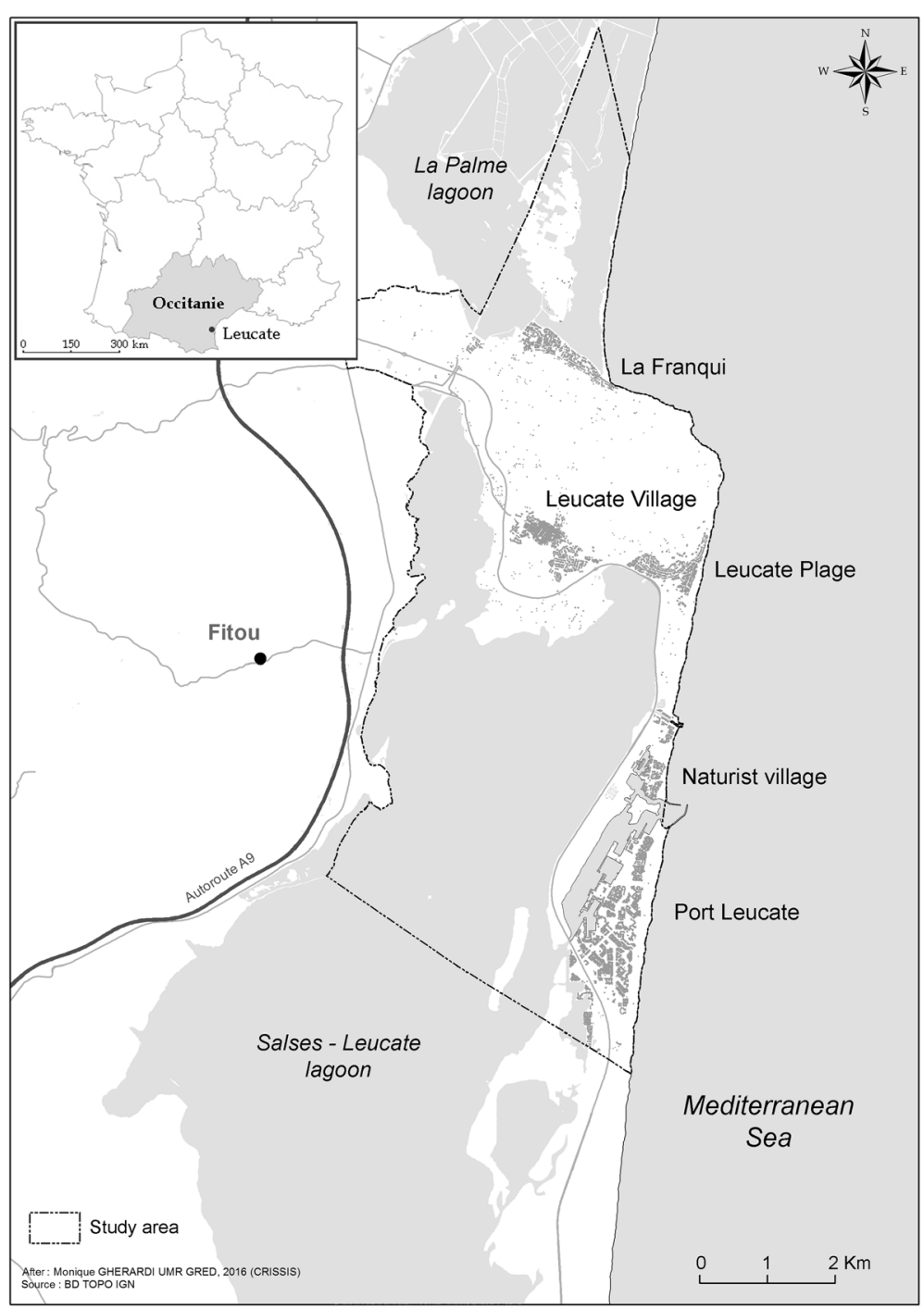

Fig. 1 Location of study area

one for several years, and to this day this document has not made it past assessment stage. A local Municipal Safeguarding Plan (PCS) was adopted in December 2014 after the town was hit by two violent storms in March 2013 and November 2014.

In this context combining strong hazard and major vulnerability, the local authorities only appear to have become aware of risk very recently. The town of Leucate therefore provides an interesting site to experiment with the integrated and operational marine submersion risk management approach developed by the CRISSIS program.

\section{Methodology: An integrated and operational approach to marine submersion risk}

The CRISSIS approach integrates the three dimensions of submersion risk:
- The hazard and its predictable evolution in the context of climate change: digital simulations of sea level variations caused by storms or other factors, and of runoff propagation into urban areas, and high-resolution mapping of findings;

- Vulnerability: structural vulnerability of buildings and human vulnerability of inhabitants (based on age and mobility criteria), mapping of potential damages to constructions and associated human issues;

- Perceptions and representations held by the population (or "risk culture"), captured through a geo-sociological survey aimed at quantifying risk culture levels; production of a map of findings to help improve information management and awareness-raising activities.

This project aims to improve both risk prevention and crisis management by local authorities. This aspect forms 
the fourth phase of the program: it consisted in developing exercises to test crisis management mechanisms and procedures based on existing operational documents (PCS), complemented by new data produced through our analysis of the three dimensions of risk.

\section{Analyzing hazard using a numerical modeling system}

In France, coastal flood hazards are still often approached through basic mapping methods obtained by cross-referencing the topography of exposed areas with extreme water levels, estimated through a statistical analysis of marine weather forcing conditions. This methodology was for instance used to elaborate official risk exposure documents (Coastal Flood Risk Prevention Plan or PPRSM) for the Mediterranean coastline. These basic methods are not however suited to optimal crisis management. They only produce schematic maps that do not include the event's kinetics, the detail of the process that caused the flood (inundation, overtopping of a barrier, breaching of flood defense structures...), or the specificities of water propagation in urban area. Furthermore, this type of mapping associates the hazard with extreme statistical characteristics, which is not always compatible with the need for precise information in cases where the crisis might have been caused by a lower-intensity event.

Digital modeling is now increasingly used to map out hazards, using chains of models to recreate the process that caused the flood: inundation, overtopping, breaching of flood defenses, etc. (Gallien et al. 2014; Guimarães et al. 2015; Le Roy et al. 2015; Nicolae et al. 2018). Recent improvements, both in terms of technical developments and of pre- and post-data processing, have made it possible to integrate both the phenomena that contribute to floods (rise of average sea level, waves, river water) and their chronology (duration of floods, breaching of defense structures, synchronicity of the maximum values of sea and river levels). This has made it possible not only to identify risk areas, but also to evaluate timescales and potential response times between the start of an event and the point where communication lines or strategic buildings are damaged. Some important efforts are currently being deployed using meta-modeling or machine learning to achieve a real-time forecast of floods (Goulby et al., 2014; Jia et al., 2015; Rohmer et al., 2016). However, this work remains too experimental to be used in an operational setting. The most effective solution for mapping out such hazards remains combining a statistical analysis of the varying intensity of marine weather conditions with a field diagnosis of local vulnerabilities (coastal narrow dune, fragile seafront structures, water drainage system...): we can thus elaborate multiple scenarios in consultation with local stakeholders, and produce a tool to support decision-making in crisis situations.
The CRISSIS project therefore chose to work from a numerical modeling system to characterize flood hazard. The modeling is based on a chain of models MARS (Lazure and Dumas 2008), SWAN (Booij et al. 1999), SWASH (Zijlema et al. 2011) - in order to model the variation in sea levels caused by storm conditions (atmospheric pressure, wind set-up) and the contribution of wave set-up to the rise of average sea levels, and to assess the volume of water overtopping the seafront and the propagation of the water on land (Nicolae et al. 2015; Nicolae et al. 2018). The modeling process comprised of two stages.

\section{Stage 1: Testing and validating the modeling system}

The test consisted in simulate two recent storms (March 2013 and November 2014) that presented diverse weather conditions and consequences in terms of flood on the area of study. The all description of the validation process is detailed in Nicolae et al. 2018 and only main results are presented here. Data, which was used to recreate similar weather conditions on the site of Leucate, is listed in Table 1.

Information has been collected from multiple sources (press, photos, interviews, testimonies, report from technical services, etc.) to characterize flood events (intensity, sea level, chronology). We were thus able to retrace the affected areas and the chronology of events. These observations, although mostly of a qualitative nature, enabled us to estimate the level reached locally by the flood based on human landmarks (sidewalks, walls, quays). These points of observation were cross-referenced with LIDAR data and/or DGPS measurements collected through a field campaign, in order to quantify in term of water height each qualitative observation. The reach of the flood waters extension limit in the most heavily affected areas was also mapped out, consulting local authority staff who had worked on the ground during the storms. In the absence of local records of water levels in the port, the information collected and converted in water height (in reference to the French terrestrial datum, IGN69) provided a valuable information to assess the quality and precision of the modeling of water levels and submersion in various sites

Table 1 Observed and simulated data

\begin{tabular}{|c|c|c|c|}
\hline \multirow[t]{2}{*}{ Data } & & \multicolumn{2}{|l|}{ Past events } \\
\hline & & March 13 & Nov 14 \\
\hline $\begin{array}{l}\text { Sea } \\
\text { levels }\end{array}$ & Observed & SHOM tide gauge in Sète & $\begin{array}{l}\text { SHOM tide gauge in } \\
\text { Port La Nouvelle }\end{array}$ \\
\hline \multirow[t]{2}{*}{ Waves } & Observed & Candhis buoy, Leucate & $\begin{array}{l}\text { Candhis buoy, } \\
\text { Leucate }\end{array}$ \\
\hline & Simulated & $\begin{array}{l}\text { Model IFREMER } \\
\text { MEDNORD }\end{array}$ & $\begin{array}{l}\text { Model IFREMER } \\
\text { MEDNORD }\end{array}$ \\
\hline Winds & Observed & $\begin{array}{l}\text { France Leucate weather } \\
\text { station }\end{array}$ & $\begin{array}{l}\text { France Leucate } \\
\text { weather station }\end{array}$ \\
\hline
\end{tabular}


across the municipality. The water levels generated through the simulations were compared with those deduced from the analysis of topographic landmarks (quays, roads) that appeared on photographs to be submersed or not by the floods. By looking at various landmarks across the port area, we established that the average water level in the port was $0.85 \mathrm{~m} \mathrm{IGN}+/-5 \mathrm{~cm}$ IGN in 2013, and $1.05 \mathrm{~m} \mathrm{IGN}+/-5 \mathrm{~cm}$ in 2014. The water levels generated by simulations in the area were within a similar range to those estimated from photographic observations (a discrepancy of under $5 \mathrm{~cm}$ was observed for the 2013 simulation, and an underestimation of about $10 \mathrm{~cm}$ for 2014), which indicated that the performance of the modeling system was relatively reliable.

\section{Stage 2: Elaboration of submersion scenarios}

After validating the modeling system, we developed various submersion scenarios, based on a multivariate statistical analysis of extreme values (joint probability of waves/water levels). This analysis enabled us to define low-probability marine conditions (with a return period of 100 years), which were propagated to the shore and then to the land (Nicolae et al. 2018). These simulations enabled us to characterize the reach and intensity of floods for hundredyear events, and to anticipate the consequences of a gradual rise of the average sea level under the effect of global warming. This data was fed into a GIS in order to create relevant maps for crisis management exercises.

\section{Assessing the vulnerability of buildings and populations}

Over the past few years, the geographic understanding of natural hazards shifted from a hazard-centered approach to a vulnerability-centered approach, integrating the social dimension of hazard. Such a diagnosis and evaluation of vulnerability presents advantages in terms of anticipating risk and mitigating its impacts. Although this notion has evolved, vulnerability can be understood both in its primary meaning as the capacity to withstand damage (D'Ercole et al. 1994) but also as the capacity to cope with damage (Thouret and D'Ercole 1996), thus echoing the concept of resilience. Resilience is perceived as the positive counterpart to vulnerability, which usually carries negative connotations due to its association with fragility, although the two terms are not mutually exclusive (Reghezza Zitt and Rufat 2015).

This study considers the geographic dimension of risk on an infra-municipal scale, with a vulnerability diagnosis focusing on individual issues (on the scale of a building). The notion of vulnerability implies an assessment-centered approach (Leone et al. 1996; Becerra 2012), which must begin with the identification of criteria and indicators. Many recent studies on the subject show the relevance of this methodology (Barroca et al. 2005; Leone 2007).
As part of this research project in Leucate, the diagnosis of material and human vulnerability was evaluated on multiple scales. We first assessed the vulnerability of material goods exposed to hazards, considering that vulnerability also affects the rest of the area (D'Ercole and Metzger 2009). In addition, we carried out a comprehensive diagnosis of material and human vulnerability, considering the dangerousness of each building located in a high-risk area in the municipality. Within this sample, we carried out a diagnosis of first homes, second homes and tourist accommodation (about 4000 buildings) as well as commercial premises (about 100). However, to further elaborate our vulnerability criteria - and more specifically those relevant to human vulnerability - a diagnosis was drawn based on a perception survey (see below). Additional evaluation criteria were used for this sample, but they only covered 400 buildings (tourists who do not own their accommodation were excluded from the sample).

The criteria were set to capture the potential damages caused by coastal floods, assessing both material vulnerability (type and condition of building) and human vulnerability with indicators assessing people's access to safety. The advantage of using two different samples was that they provided an operational diagnosis across the area affected by risk. This also helped us respond to the expectations of local authorities, by showing that a more in-depth diagnosis could be carried out to improve crisis management by identifying and locating vulnerable individuals.

The surveys included questions based on vulnerability criteria and indicators (extract: see Table 2). The methodology used to assess vulnerability was adapted to the local context of the municipality of Leucate, using evaluation criteria that had been designed for other locations and hazards and had been proven to be relevant to this site (Leone 2007; Meur-Ferec et al. 2011; Lagahé and Vinet 2014).

Some criteria capture both material and human vulnerability, while others only capture one type of vulnerability.

A vulnerability index was developed from these criteria. When taken individually, a criterion only captures a partial assessment of one specific type of vulnerability. However these criteria and indicators can be combined to provide a global assessment of vulnerability, where some criteria are compensated by others.

The methodology followed to create this index consisted in setting a hierarchy between indicators and criteria, by using an intra- and inter-criteria weighing system. The hierarchy was based on the bibliography and on past studies on this topic, as well as on a global reflection on the importance of a given criteria in comparison with another, always from the perspective of a scenario of potential damage. We were thus able to elaborate maps that were fed into the development of crisis exercise scenarios. 
Table 2 Extract from list of vulnerability criteria and indicators applied to Leucate (the sample of individuals surveyed)

\begin{tabular}{|c|c|c|c|c|}
\hline $\begin{array}{l}\text { Inter-criteria } \\
\text { weighting }\end{array}$ & Criteria & Indicators & $\begin{array}{l}\text { Intra-criterion } \\
\text { weighting }\end{array}$ & \\
\hline \multirow{5}{*}{$\begin{array}{c}0 \text { to } 6 \\
\text { depending on } \\
\text { criteria }\end{array}$} & Type of property & $\begin{array}{l}\text { Multi-storey accommodation; single-storey with roof exit; single-storey } \\
\text { without roof exit. }\end{array}$ & 0 to 8 & $\begin{array}{l}\text { Material } \\
\text { vulnerability }\end{array}$ \\
\hline & $\begin{array}{l}\text { Structure and condition } \\
\text { of property }\end{array}$ & $\begin{array}{l}\text { Age of accommodation; floor level; types of materials; waterproofing } \\
\text { of openings; height of electrical connections. }\end{array}$ & 0 to 4 & \\
\hline & $\begin{array}{l}\text { Type and structure } \\
\text { of property }\end{array}$ & $\begin{array}{l}\text { Multi-storey accommodation; single-storey with roof exit; single-storey } \\
\text { without roof exit; ground floor level; number of bedrooms and inhabitants }\end{array}$ & 0 to 8 & $\begin{array}{l}\text { Human } \\
\text { vulnerability }\end{array}$ \\
\hline & Accessibility & Type of access road; emergency exits & 0 to 4 & \\
\hline & $\begin{array}{l}\text { Characteristics of } \\
\text { population }\end{array}$ & $\begin{array}{l}\text { Number of persons; under } 10 \text { years old; over } 60 \text { years old; over } \\
80 \text { years old; persons with reduced mobility and/or dependent persons }\end{array}$ & 0 to 3 & \\
\hline
\end{tabular}

\section{Perception analysis and representations of risk}

An understanding of the perceptions, behaviors and reactions of individuals and groups of individuals in the face of any kind of risk should form a prerequisite to the development of prevention and management policies (Ruin 2010). This process can help researchers better grasp the discrepancy between the knowledge of experts and that of laypersons (Baggio and Rouquette 2006). The perception of risk varies between individuals: studies on this topic attempt to characterize groups of individuals that share a relatively similar perception of a given risk (Hellequin et al. 2013). An individual's perception of risk is influenced by four factors: their experience of risk (through direct or indirect experience), their knowledge on this risk (lay or academic), their social and economic interests (attachment to a place, value of property, socio-economic standing of household, etc.), and their values (moral, political, etc.). Over the past twenty years, the analysis of perceptions and social representations has played an increasingly prominent part in research programs on French coastal towns' vulnerability to marine hazards (Goeldner-Gianella and Chionne 2014; 2002-2004: PNEC, Nord-Pas-de-Calais; 2007-2011: ANR MISEEVA, Languedoc - Roussillon; 2011-2014: ANR COCORISCO, Bretagne, etc.). These studies have highlighted the weakness of social representations of coastal risks (erosion and marine submersion) and even the "blatant absence of a risk culture" (Chauveau et al. 2011). Most surveys show that the populations affected feel little concern for coastal risks. They do not reflect on their situation, and nor do they actively seek out information or design any action plans in the event of a disaster (Hellequin et al. 2013; Flanquart 2014; Krien 2014). When questioned, the people surveyed tend to make up a spontaneous discourse on the question by drawing from their memories, sensations and incomplete reflections on the question. Krien (2014) explains that people's representation of coastal risks is the product of a social construct developed from their overall representation of risk, the sea, storms and the place where they live.
In order to measure risk culture levels in the municipality of Leucate, the methodology focused on three main angles: questionnaire-based surveys of inhabitants; semi-structured interviews with key stakeholders; and a discourse analysis of the local news bulletin, Cap Leucate. In total, we screened 46 issues ranging from January 2010 to June 2015 (the bulletin is monthly in theory), which underwent an assisted textual analysis using the Tropes software (Pont 2015). The term "submersion" ("submersion") appears in the newsletter for the first time in the March 2015 issue, to refer to the municipal rescue plan established by the local authorities, and in an article that announces the launch of the CRISSIS research project. Before the creation of official documents (PCS and PPRL), municipal authorities would use the word "inondation" ("inundation") when referring to coastal floods. The word "inondation" was written sixteen times, including three times during the 2013 flood that hit Leucate Plage, and three times in 2015 in relation to the announcement of this research program.

The questionnaire survey was communicated to 493 people including first home owners, holiday home owners and tourists living in Port Leucate, the naturist village and Leucate Plage (Table 3). The survey was carried out from april to june 2015. At this time of year, many holiday homes are unoccupied, making it easier for us to survey residents and secondary home owners. The surveys were conducted face-to-face at the respondents' homes and lasted 20 to $40 \mathrm{~min}$. The people present were rather suspicious, we had several refusals. Overall, the questionnaires were well completed, with respondents answering 93\% of the questions. It would have been useful to base our population and location sampling on the modeling of submersible areas and of the vulnerability of buildings, which were described above. However, as the duration of the program was limited to two years, we had to carry out all research activities simultaneously, and were not able to use this sampling methodology. Individuals were surveyed on: (1) the appeal of the Leucate municipality and its leisure activities; (2) their perception of the 
Table 3 Breakdown of surveys in Leucate based on area of residence and residential profile of individual surveyed

\begin{tabular}{lllll}
\hline $\begin{array}{l}\text { Resident profile / } \\
\text { surveyed area }\end{array}$ & First home owners & Second home owners & Tourists & Total \\
\hline Leucate Plage & $2 \%(n=12)$ & $4 \%(n=18)$ & $9 \%(n=42)$ & $15 \%(n=72)$ \\
Naturist village & $5 \%(n=23)$ & $4 \%(n=20)$ & $1 \%(n=3)$ & $9 \%(n=46)$ \\
Port Leucate & $32 \%(n=158)$ & $36 \%(n=174)$ & $9 \%(n=43)$ & $76 \%(n=375)$ \\
Total & $39 \%(n=193)$ & $43 \%(n=212)$ & $18 \%(n=88)$ & $100 \%(n=493)$ \\
\hline
\end{tabular}

area's and of their accommodation's exposure to coastal flood risk; (3) their awareness of this risk in Leucate; (4) their presumed reaction in the event of a submersion; and (5) their expectations in terms of communication about this risk. The final objective was to map out representations of risk, in order to help shape the local authorities' information and awareness-raising activities on coastal flood risk.

\section{Testing crisis management procedures through crisis exercises}

\section{Crisis exercises: $A$ brief state of the art}

The last stage in the CRISSIS program's integrated approach brought added operational value to the project. Recent research on risk assessment in coastal areas - for instance in the Languedoc Roussillon region, the projects RNACC ("Risques Naturels, Assurances et Changement Climatique" ["Natural Risk, Insurance and Climate Change"], Yates-Michelin et al. 2011) and ANR MISEEVA (2008-2011, Vinchon et al. 2011; Meur-Férec et al., 2011) - did not go as far as integrating crisis management. And yet the preparedness of local authorities is essential. Any failings on their part can significantly amplify the impact of extreme phenomena in coastal areas, turning a crisis into a full-blown disaster (Daniels et al. 2011; Genovese et al. 2011). This is particularly true in regions where the stakes are high and diverse, and where a crisis can involve multiple public and private stakeholders. Local players should therefore be trained in crisis management, including by organizing crisis exercises (Lagadec 1993, 2001, 2012; Stern 2014).

To meet this challenge, public authorities in many countries have developed emergency management systems for using by stakeholders and organize regularly large-scale crisis exercises to prepare institutions and populations to cope with major crises. Thus, in the USA, following huge forest fires in California and Arizona in the 1970s, which had highlighted a lack of coordination of emergency response between different actors, several states have developed the Incident Command System (ICS), which, after the attacks of September 11, 2001, was extended to all US states and integrated into the National Incident Management System (NIMS). NIMS is "a consistent nationwide approach for Federal State, and local governments to work effectively and efficiently together to prepare for, respond to, and recover from domestic incidents.. To provide for interoperability and compatibility among Federal, State, and local capabilities, the NIMS will include a core set of concepts, principles, terminology, and technologies covering multi-agency coordination systems; unified command; training; identification and management of resources ; qualifications and certification; and the collection, tracking, and reporting of incident information and incident resources" (Anneli 2006). To regularly train the stakeholders, the FEMA (Federal Emergency Management Agency) has a National Exercise Program, https://www.fema.gov/ned) which regularly runs large-scale drills simulating the occurrence of cyclones, earthquakes and tsunamis. In Europe, this task is covered by the European Civil Protection Mechanism (ECPM, http://ec.europa.eu/echo/what/civil-protection/mechanism_en) which organizes and funds a series of drills in the field of civil protection in different member countries every year. The French example provides a good gauge for a national policy for crisis drills. With a concern for optimizing the response from stakeholders and the public in a crisis, the 2004 law on the modernization of civil security (law \#2004-811 dated 13 August 2004) makes regular exercises compulsory, with a requirement for large-scale drills several times a year at national and regional levels (Richter-type earthquake drills are a good example) and a requirement for all towns and villages where a major natural or technological risk has been identified to conduct at least one crisis drill per year (DGSCGC or Direction Générale de la Sécurité Civile et de la Gestion des Crises, 2008). According to the guidelines set by the General Directorate for Civil Security and Crisis Management (DGSCGC), a body whose equivalent can be found in most countries, there are two main types of exercises (Institut National des Hautes Etudes de la Sécurité et de la Justice (INHESJ) 2015): "table-top exercises" ("exercices cadres") and "field conditions exercises" ("exercices terrain"). The former are desk-based and take place at the crisis headquarters. They do not involve the deployment of any resources on the ground. Participants receive information by radio, phone, fax, television, SMS and the social networks. They are required to analyze, and synthetize this information, react, report to others, make propositions, set priorities and make choices to manage the crisis 
for the better. The second type involves the deployment of men and equipment on the ground. One of its objectives is to test the transportation and deployment of equipment in real-life and real-time conditions. Good examples of such activities include the exercises organized periodically in the US by the FEMA or those organized by area prefectures in France. For instance, the European Sequana 2016 exercise, held in March 2016 and which simulated the occurrence of a 100-year flood of the Seine in Paris, involving public stakeholders at various levels (national, zonal, departmental and municipal) and an array of private operators (transport firms, telecommunications companies, banks, supermarkets, hospitals, and so on). On the one hand, the goal of this exercise was to test Paris area regional stakeholders' ability to coordinate and to cope with response and crisis management. On the other hand, that test was also an opportunity to assess the relevance of operators' crisis management plans as well as the consistency of operational procedures. Eventually, public authorities were also provided with a feedback and the scope of information for population was measured for ensuring their awareness can be improved in the event of a disaster. The exercise uncovered two points to improve in the emergency response: the coordination of public and private actors, very heterogeneous according to the sectors of activity, and the information of the population, which sometimes lacked efficiency (some instructions have not been well assimilated) (Creton-Cazenave and November 2017). However, in France, in spite of these efforts, crisis exercises remain all too rare, especially at local level. In its 2012 activity report, the French Committee for Civil Defense (Haut Comité Français pour la Défense Civile (HCFDC) 2012) pointed out that in France "crisis management procedures are too often untested" for high-intensity events. In addition, such exercises, whether they are "table-top" or "in real conditions" exercises, take place at the initiative of major public institutions (government agencies, prefectures, civil protection departments) but are rarely if ever initiated by the research sector.

In this context, the CRISSIS program aimed to test the municipality's current crisis management procedures (set in the December 2013 PCS) and help optimize them through two crisis exercises involving local stakeholders, organized and designed according to a principle of progressivity.

\section{Methodology of program exercises}

The first exercise took place at the start of the program in March 2015. It consisted in a simple training session aimed at informing the municipality's senior administrative staff (Head of municipal police, Head of technical department, Director General of administration) of the main procedures and mechanisms listed in the Municipal Rescue Plan, which had recently been adopted. This session did not include the program's findings on hazard analysis, vulnerability and population perceptions/representations. The training followed the format of a framework exercise, which was organized in Paris by students from the Master's degree "Gestion Globale des Risques et des Crises" ("Global Risk and Crisis Management", or GGRC), working from a low-intensity crisis scenario. In practice, the exercise ran over three hours and the participants broke out into two units: (i) a "facilitation" unit where the participants played the parts of Préfecture staff, firefighters, security forces, the media and the population, who were responsible for sending "inputs" based on the chosen scenario to (ii) the crisis unit that simulated the work of the municipal command team (PCC).

Following this first training session, a second, more ambitious exercise took place locally a year later, in March 2016 (duration: $3 \mathrm{~h}$ ). This time, the exercise involved all the municipal staff including elected members of the Council, as well as senior representatives of the local authorities: the Préfecture of the Aude département (where Leucate is located), département managers of the fire brigade and the DDTM ("Direction de l'Aménagement et du Territoire", or "Planning and Territorial Directorate", a devolved State body in charge of risk prevention). This time, the session included both framework and field activities. Some elements were performed in a real-life setting (on-the-ground deployment of technical staff and municipal police forces) to test the coordination of the municipal crisis unit (municipal command team, or PCC), with resources deployed on the ground. However, because of financial and public security constraints, it was not possible to perform the entire exercise in real-life conditions: for instance, civil safety (firefighters) and security forces (gendarmerie) were not involved in real life but fictionally. Facilitators played the part of the media (television, press), the social networks, the population affected by the crisis and the private operators involved.

This time, the scenario included new data (on hazard and vulnerability) acquired during the project's previous stages. The main objective was to test the "marine submersion" section of the PCS to which detailed specific and intermediary objectives had been added, as shown in Table 4.

The scenario was entirely designed by the students of the GGRC Master's degree from Université Paris 1, under the supervision of crisis exercise specialists, and with the assistance of two senior members of municipal staff (the Head of environment and a Municipal Police manager) as well as a manager from the Aude préfecture (deputy risk manager) who brought their field experience on board and helped develop credible "inputs". The danger when creating such exercises is that participants might in retrospect challenge their credibility - for instance because they consider that their impact was too low or too high, or too remote from real-life situations. 
Table 4 Extract from the objectives of the March 2016 exercise

\begin{tabular}{|c|c|c|}
\hline Global objective & Intermediary objectives & Specific objectives \\
\hline \multirow{5}{*}{$\begin{array}{l}\text { Testing the marine } \\
\text { submersion section } \\
\text { of the PCS }\end{array}$} & $\begin{array}{l}\text { Testing the SAIP } \\
\text { (SIRENS) / SMS Alerts }\end{array}$ & Testing the logbook \\
\hline & $\begin{array}{l}\text { Understanding the PCS } \\
\text { and its role in the crisis } \\
\text { room }\end{array}$ & $\begin{array}{l}\text { Testing the relevance } \\
\text { and proficiency of the } \\
\text { crisis room's tools }\end{array}$ \\
\hline & $\begin{array}{l}\text { Confirming the crisis } \\
\text { management sites }\end{array}$ & Testing communication \\
\hline & $\begin{array}{l}\text { Testing the municipality's } \\
\text { organization in the event } \\
\text { of a crisis (staff, } \\
\text { communications, etc.) }\end{array}$ & $\begin{array}{l}\text { Testing the power } \\
\text { generator }\end{array}$ \\
\hline & $\begin{array}{l}\text { Testing the municipal } \\
\text { staff's knowledge and } \\
\text { understanding of } \\
\text { the PCS }\end{array}$ & $\begin{array}{l}\text { Testing connections } \\
\text { (phone, radio) }\end{array}$ \\
\hline
\end{tabular}

If this had been the case, the exercise would not have achieved its learning objective of consolidating the municipal staff's knowledge of crisis management tools and procedures, and where possible helping improve them. It was therefore essential for this scenario to be developed in collaboration with individuals who had an excellent knowledge of local realities and institutions.

Stimuli were produced on two levels: (i) at Préfecture level, by staff based at the Interdepartmental Service of
Defense and Civil Protection (Service Interdépartemental de Défense et de Protection Civile, SIDPC) of the Aude Préfecture in Carcassone (sent out emergency notifications from the Préfecture, responded to the municipality's requests for additional resources); (ii) at municipal level, from a site in Leucate, by the students from the GGRC Master's and by the town's two contact persons (sent out all other "inputs": reports of local damage caused by the storm, requests from the population, media queries, pressure on the social networks, etc.). The crisis was simulated on the evening of Saturday 9 April 2016 - that is, over a weekend during mid-tourist season (the week-end before a major sporting event organized in Leucate, the "Mondial du Vent"). During this period the town usually hosts 8000 to 10,000 people (for a permanent resident population of 5000) staying in secondary homes, campsites and camper van parks. Figure 2 shows an overview of the roll-out of the three-hour exercise, which has also been documented in a film that is available on the program website (http://crissis2015.free.fr/).

\section{Results and discussion}

Production of high-resolution marine submersion maps The validation of the digital modeling system and the multivariate statistical analysis of extreme values on record

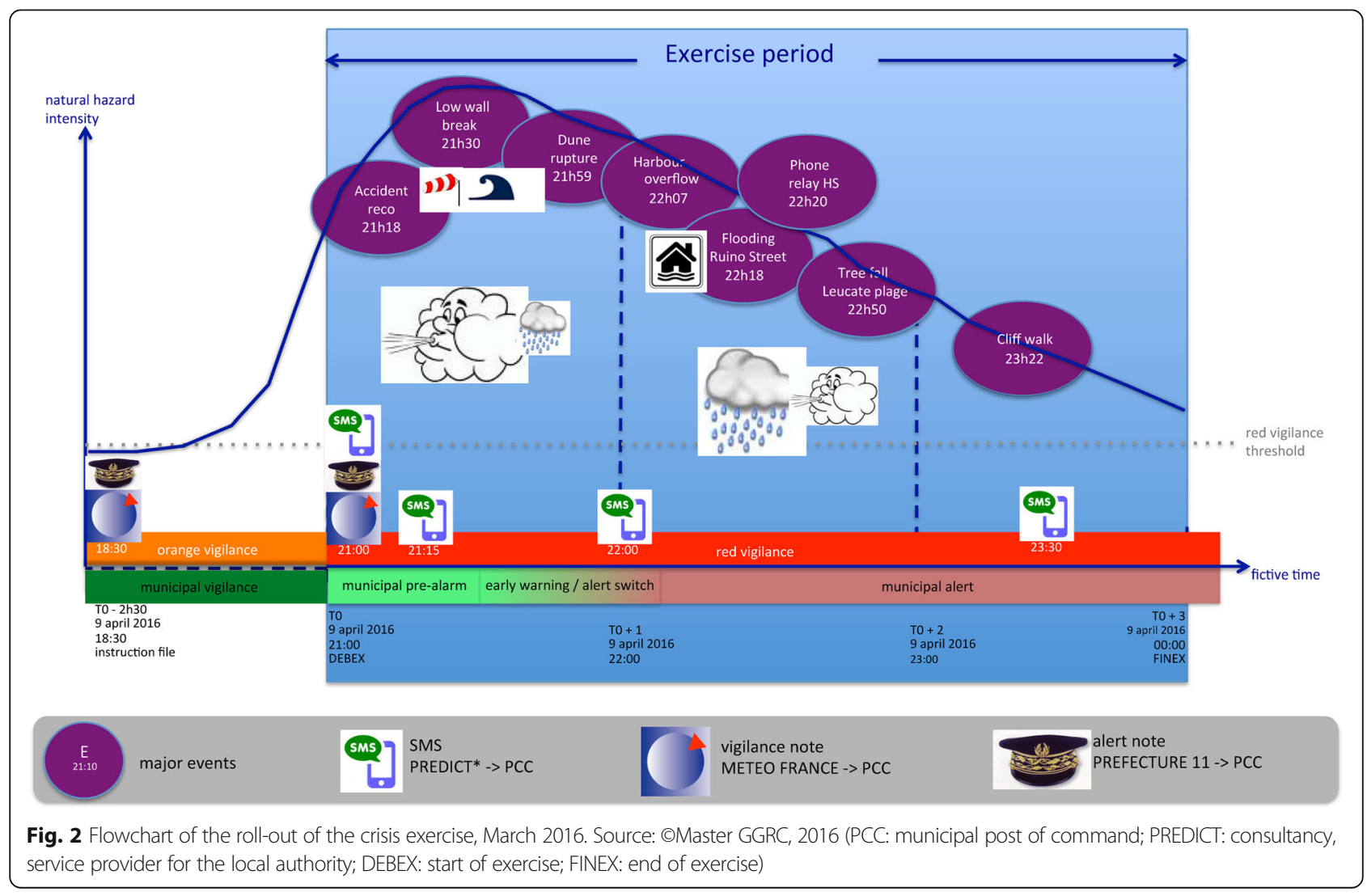


(see above) enabled us to elaborate several submersion scenarios. Simulations were run to characterize the spread and intensity of submersions for a hundred-year event (Nicolae et al. 2018), and to forecast the consequences of a gradual rise of the average sea level under the effect of climate change. For this purpose, we estimated the impact of a minor rise in sea level working from a variation of $+0.2 \mathrm{~m}$ (the average global rise forecasted according to the median scenario for the 2046-2065 period in comparison with 1986-2005 - source: IPCC WG1 Ch13, Church et al. 2013) and $+0.6 \mathrm{~m}$ (the average sea level rise forecasted in the Mediterranean by 2100, Slangen et al. 2014).

For the March 2016 crisis exercise, our consultation with the two members of municipal staff who contributed to the script drove us to simulate a coastal flood caused by a twenty-year storm, which combined the characteristics of the last two major storms (March 2013 and November 2014) in terms of wave height and sea levels - the former had caused the breach of a seafront wall in Leucate Plage, and the latter had provoked a flood by overtopping on the seafront and overflowing in Port Leucate (Fig. 3). The objective was therefore to engage the municipal staff in a role play using a scenario that combined events they might already have encountered, but separately. This helped ensure that the scenario had enough impact to place the players under pressure, while not being too "overblown", which could have been the case with a simulation of a hundred-year storm that factored in the rise of the average sea level.

\section{Mapping out critical vulnerability levels}

The analysis of vulnerability using the method described above enabled us to establish a vulnerability index (see Table II), which was mapped out to highlight the most vulnerable buildings and populations. For Leucate, three categories were defined and prioritized, ranging from low to medium and high vulnerability (Figs. 4 and 5).

Spatial mapping makes it possible to draw comparisons within one single entity, but also between entities themselves, highlighting in this case a variation in levels of material vulnerability between areas. After assessing vulnerability, this ongoing study aims to recommend strategies to adapt buildings depending on their exposure to risk. This diagnosis will be expanded to the totality of buildings in risk areas. By globalizing vulnerability, we will thus be able to assess not only material vulnerability but also territorial vulnerability (D'Ercole and Metzger 2009).

These maps of vulnerability were integrated to the PCS as appendixes, and made available to participants for the second exercise in May 2016. Their purpose was, where possible, to inform the first protection measures taken by municipal staff during the crisis (for instance, setting up coffer dams), as well as the organization of evacuation.

\section{A poor risk culture}

Our analysis of perceptions and representations showed a poor awareness of coastal flood risk amongst surveyed

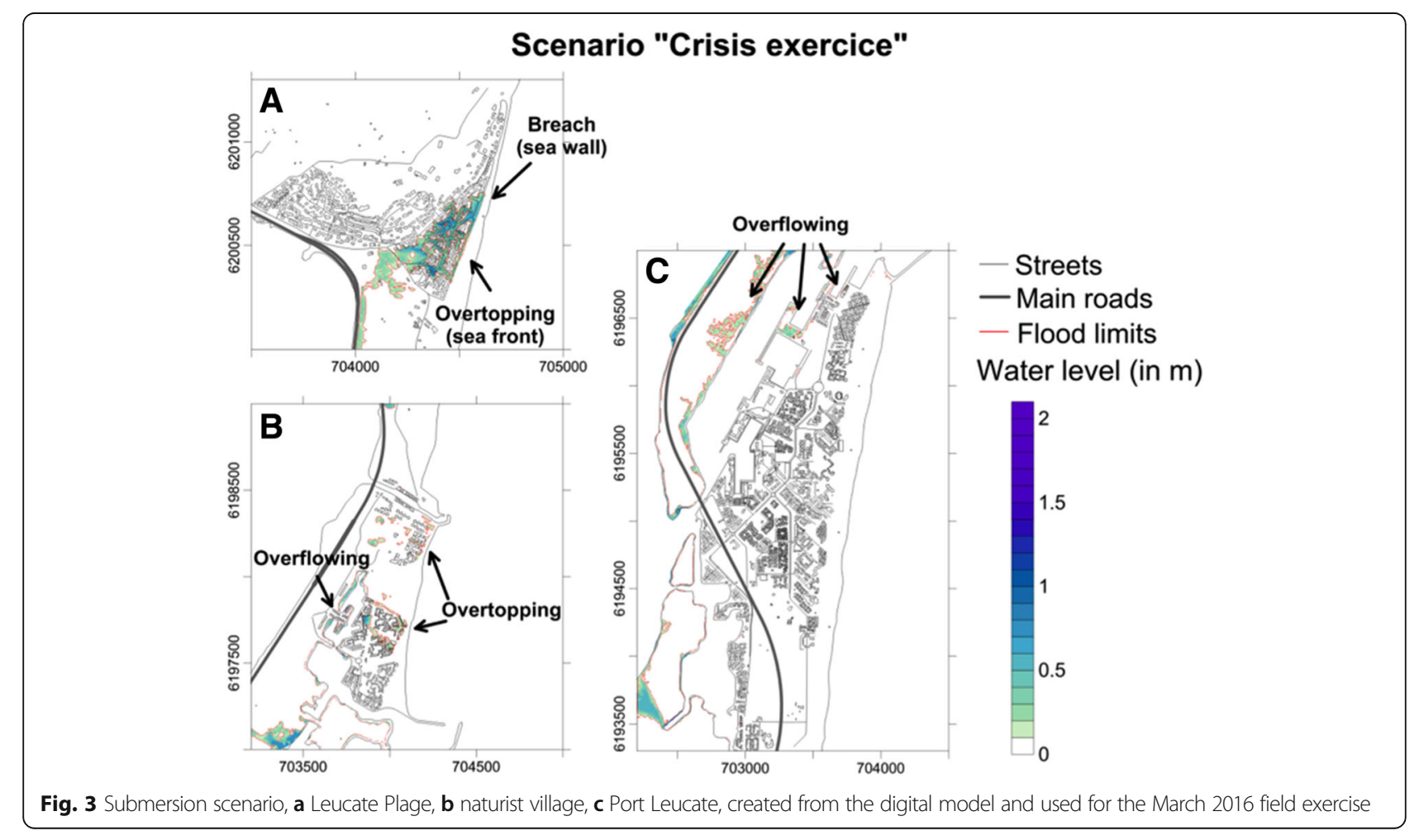



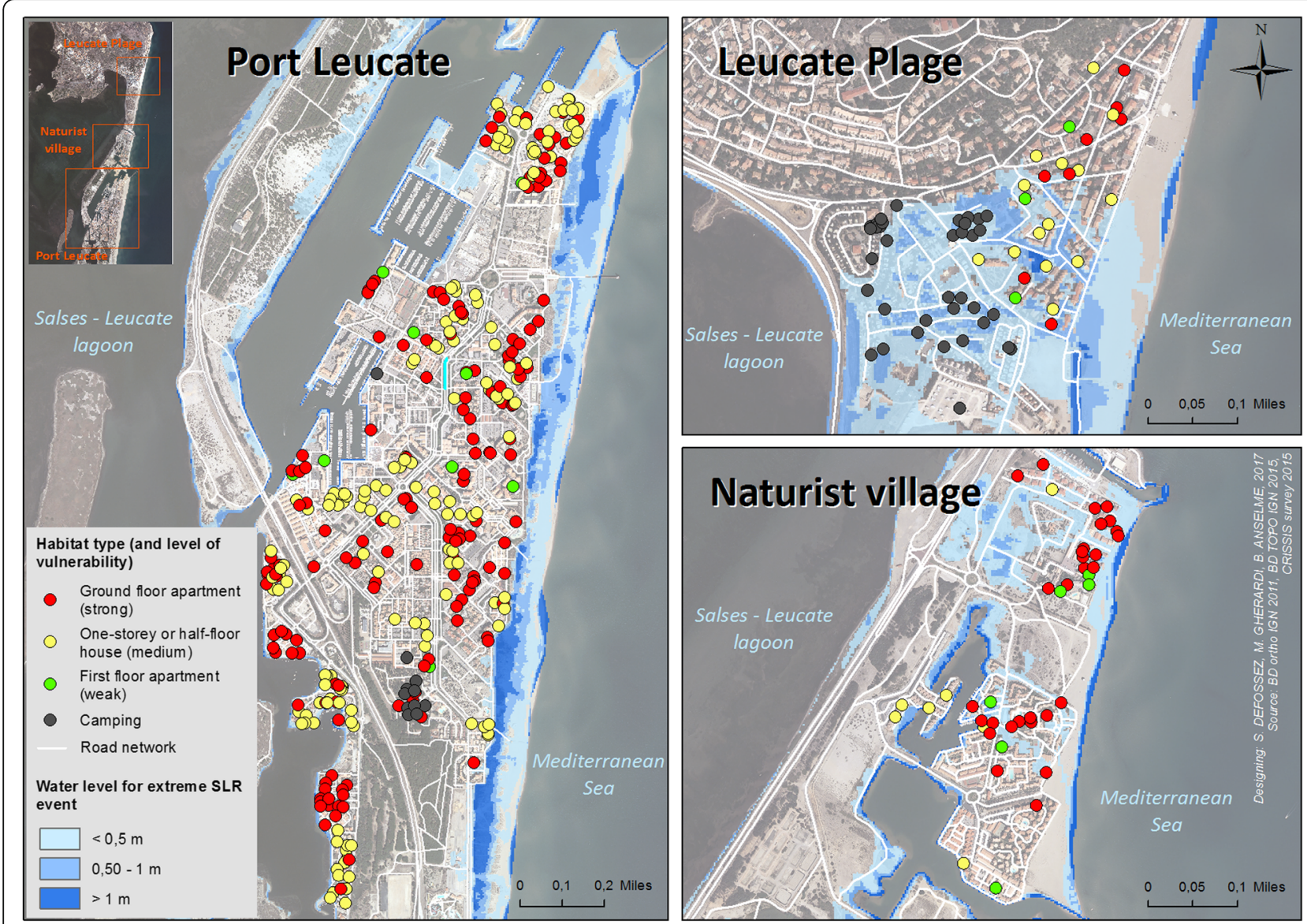

Fig. 4 Material vulnerability of people surveyed in Leucate (source: field survey)

populations. For instance, of all residents and tourists surveyed in areas that were shown by our model to be potentially submersible, only $50 \%$ of people surveyed declared that they were living in a risk area (Fig. 6).

$43 \%$ of first and second homeowners declared that the municipality of Leucate was not threatened by coastal floods. This finding is combined with an underestimation of risk. In comments recorded as annexes to the questions, some people who had been informed of past marine submersion events explained that they did not consider the few intrusions of sea water into the streets and houses as floods. According to these people, the hazard does not exist until there are human casualties, and material damage is considered unimportant and remediable. We also sought to find out whether residents were aware of the systems set up by the municipality to alert them in the event of a risk, including the volunteer-run SMS alert system outlined in the PCS. On this point, we found a significant difference between first home and second home owners: $34 \%$ of the former had communicated their contact details to the local authorities, while $74 \%$ of the latter were unaware of the existence of this system - and this despite the fact that of all second home residents surveyed, only $29 \%$ declared they were never present in Leucate between October and March (the high-risk period for coastal floods).

Consequently, it appears necessary to implement a communication strategy to inform the population, and in particular second-home owners, of existing emergency alerts. Although the findings of this study of perceptions/representations were not used in the March 2016 exercise, they informed the recommendations drafted in our exercise debrief notes to improve the municipality's information, awareness raising and communication strategy.

\section{Lessons learned from the exercise debrief: A poor integration of crisis management systems and procedures}

An exercise debrief includes a methodical analysis of the exercise, to highlight its strong points and improvement points in order to perfect the organization's crisis management processes. In this case, the scope of the lessons learned went beyond a 

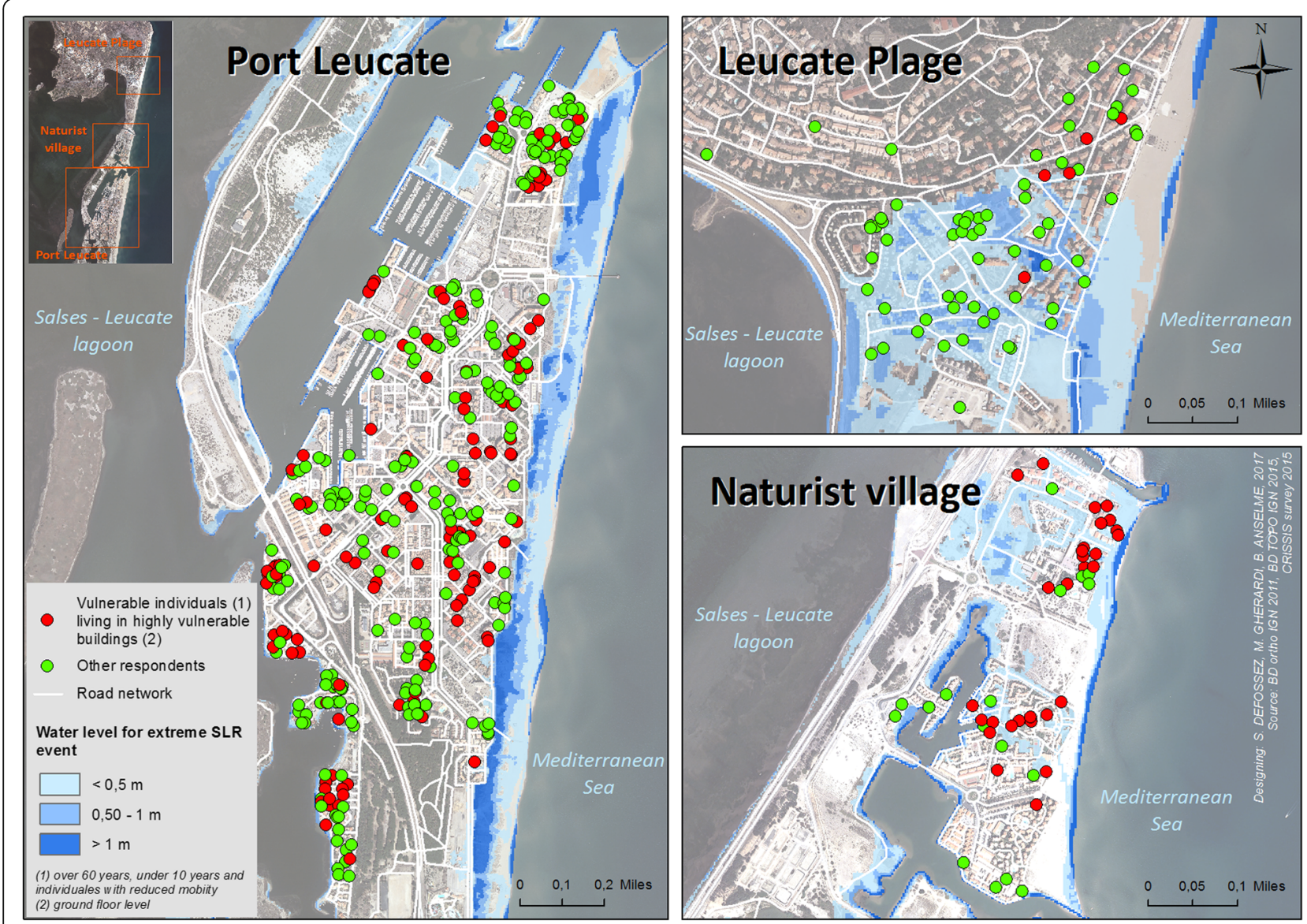

Fig. 5 Location of vulnerable populations based on age and health status (source: field surveys)

sole technical fixing of failing tools or processes. The aim was to question individual and organizational responses to extreme event that might pose a challenge to the system (Lagadec 1993).

Our debrief from the first exercise (March 2015) revealed a poor knowledge of the Municipal Rescue Plan (PCS) on the part of municipal staff, and helped us present a few observations on its contents. For instance, the PCS had no objective quantifiable milestones (in meters) regarding the water levels attained in submersed areas: the decision to activate the successive phases of the PCS (closing roadways, evacuating certain neighborhoods) were only based on field information communicated by technical staff who have been working for the municipality for years and therefore have an in-depth knowledge of local sites. However this lack of quantifiable milestones can be a disadvantage for inexperienced staff (for instance people who are new in post, or covering for more experienced permanent staff members who might be off work when a crisis occurs), leading to damaging delays in a context of emergency crisis management. Following these observations, the municipality of Leucate introduced geo-referenced flood markers into its PCS and committed to fully participating in the second exercise to improve municipal staff's command of the PCS.

The debrief for the second exercise (March 2016) was captured in a report that was presented in early May 2016 to all municipal staff. It highlighted the municipal teams' excellent field knowledge, as well as a good coordination between the municipal post of command (PCC) and the teams deployed on the ground. However, it also revealed the municipal staff's obvious lack of knowledge of the PCS: most staff had no clear understanding of their respective roles and responsibilities within the crisis unit, and therefore faced difficulties in organizing and coordinating the PCC. Furthermore, these challenges were aggravated by the crisis headquarters' lack of practicality: the functions of secretariat, command, logistics and coordination were all gathered in a single room, which caused a great deal of confusion. In this context, the fear of an error was a major source of stress, causing 

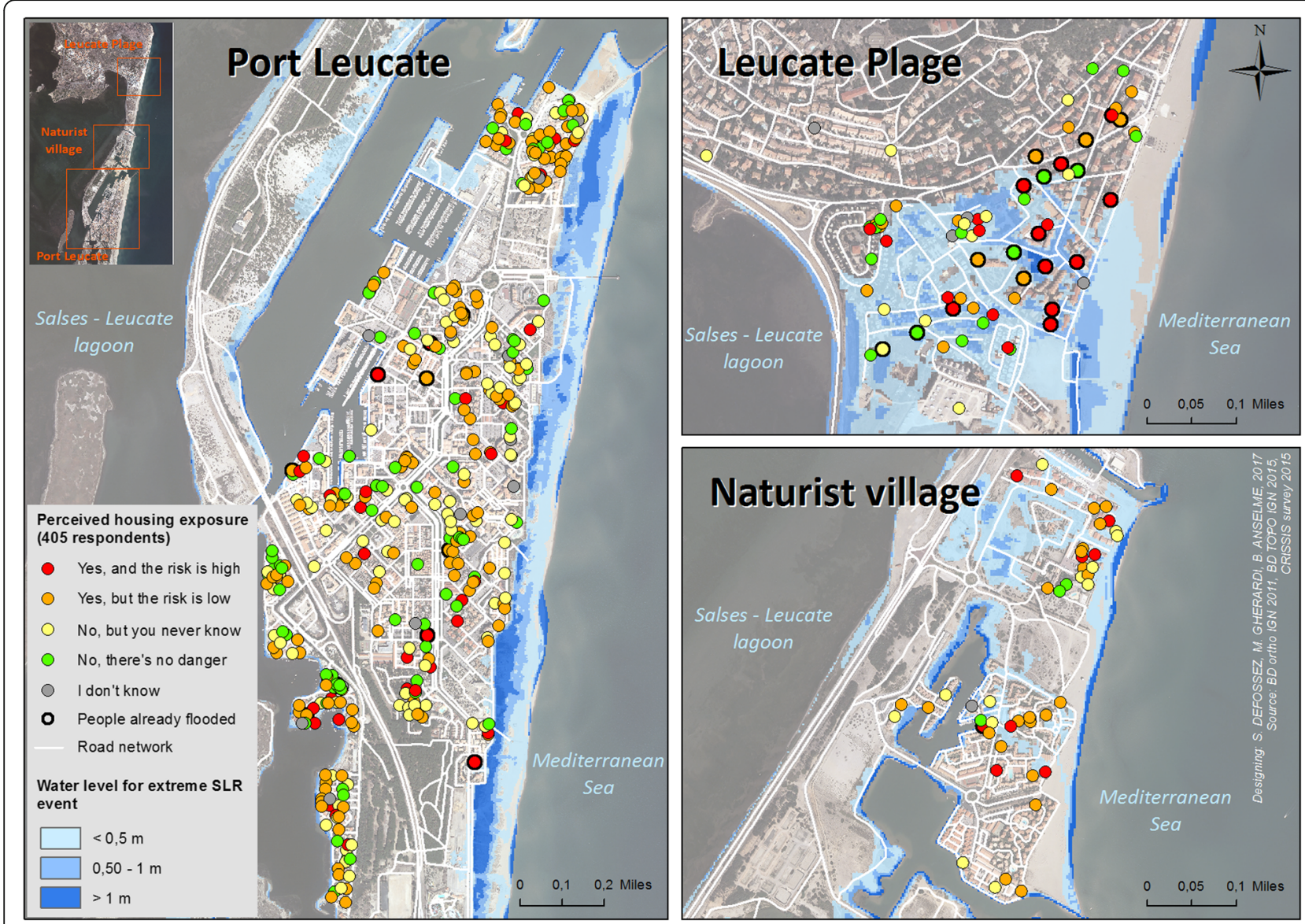

Fig. 6 Perceptions of residents on their property's exposure to marine submersion risk

communication challenges both internally within the crisis unit (absence of situation updates) and externally (communication with Préfecture services and the media). Consequently, the debrief report included four main recommendations:

(i) Reorganizing the PCC according to the traditional organizational structure of a crisis unit, to facilitate communication and decision-making in the event of a crisis. The space should be split into five open units (Fig. 7): decision-making and coordination unit; situation unit (secretariat/log); logistical unit; communication unit; forecasting unit)

(ii) Drafting concise post descriptions to be included into the PCS, so that from the moment of their arrival into the PCC each member of the crisis unit knows what their role is and what they are expected to do. Examples of post descriptions: crisis unit Director (DOS); unit Coordinator (needs to be very mobile and move between units); Secretary (keeping a log, handling calls); communication unit / forecasting unit / logistical unit Managers. (iii) Writing a checklist to be inserted at the start of the PCS, outlining the key principles of crisis management: sharing the logbook; updating the schedule and map in real time; regular situation updates, and communication of human casualties to the higher echelons (Préfecture), etc.

(iv) In addition, the municipality should improve its communication with the population ahead of the crisis (for instance via the local news bulletin) on current crisis alert systems and in particular the SMS alert (this recommendation directly derives from the analysis of perceptions/representations of risk).

\section{Discussion: What are the obstacles faced by an operational approach to coastal flood risk?}

The resolutely operational approach adopted by the CRISSIS program faced three challenges. First of all, it has been difficult to convince local representatives to organize a crisis exercise locally. While the first exercise, which took place in Paris in March 2015, did not pose any major issues as its stakes were lower (low-intensity exercise, remote location, framework exercise only, involving only two technical staff members and the Director General of 


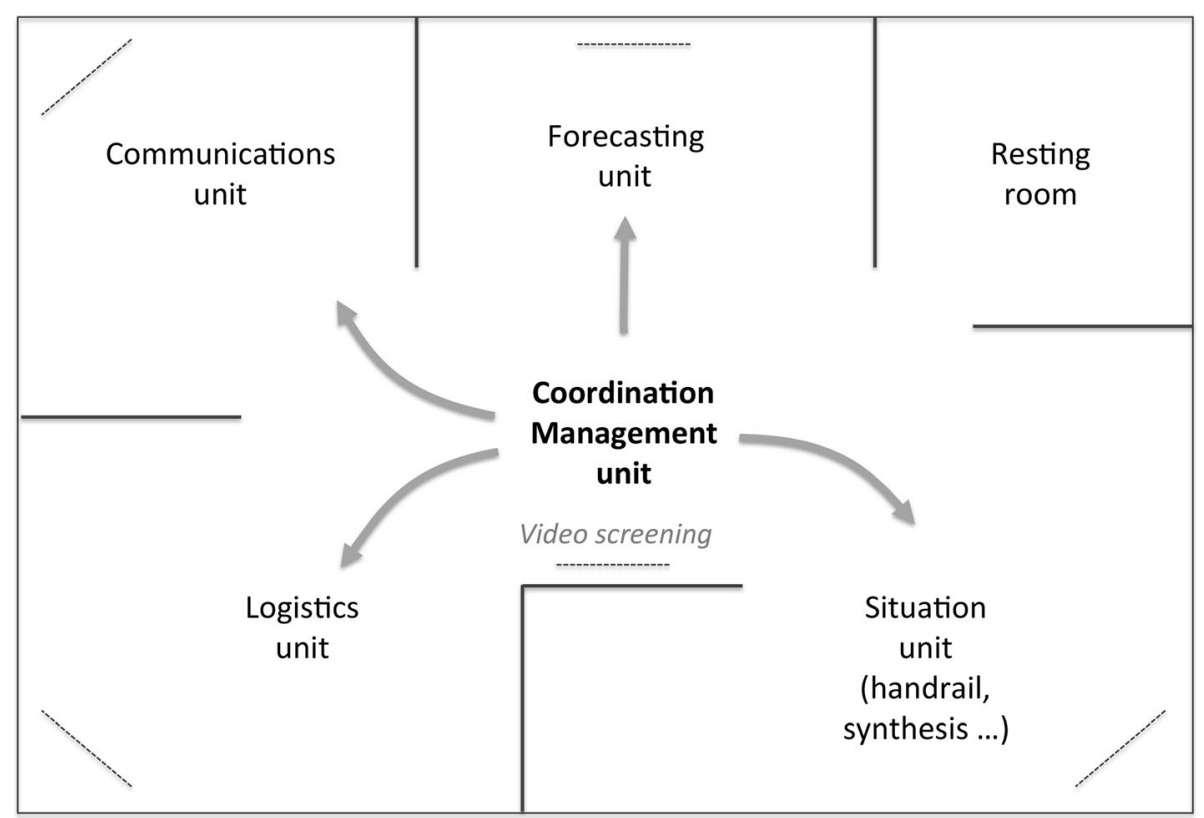

Fig. 7 Example of proposed reorganization of the PCC suggested in the exercise debrief report

municipal services as observers), organizing the second proved markedly more complex. As this exercise needed to take place locally and involve large numbers of Council members and municipal staff, we were initially faced with a clear reluctance on their part. Eventually, only two Council members (two Deputy Mayors) did take part in the exercise, along with about twenty administrative and technical staff members. The 2004 Law for the modernization of civil security (Act 2004-811 of 13 August 2004) states that any municipality where at least one major natural or technological risk has been identified must organize at least one crisis exercise per year (DGSCGC, 2008). However, as highlighted by the French Committee for Civil Defense in its 2012 report (Haut Comité Français pour la Défense Civile (HCFDC) 2012), very few municipalities actually comply with this obligation. This reluctance may be due to the lack of municipal resources, or perhaps to the fear of being evaluated and judged. In this respect, a lot of educational work is needed to convince potential participants that the objective of such exercises is not to evaluate individuals but systems and procedures, in order to improve them and make them easier to memorize. Only when the exercise was completed did participants finally drop their guard and admit to its usefulness.

In addition, municipal staff made a variable use of the operational documents (maps) presenting the findings of the analysis of hazards and vulnerability. The submersion forecast maps that were provided to the PCC coordinator (Head of the municipal police) at various points during the crisis, in replacement for the maps he would normally had received from hydro-meteorological experts Predict (the municipality's current service provider) were used properly. However, this was not the case with the maps showing people and buildings' critical vulnerability levels, which could have informed the first protection measures (for instance, setting up coffer dams) taken by personnel on the ground. This challenge shows the necessity of providing the PCC staff with user-friendly documents that can be read quickly. Similar observations had been made during the crisis exercise organized for a group of municipalities in La Réunion by students from the École des Mines in Alès as part of the only other French program on submersion risk (Wassner et al. 2016) that also included an operational dimension and a crisis exercise.

Finally, the actual adoption of the recommendations presented in the exercise debrief report is a very long-term process. Although these recommendations were approved by the municipality when the report was first presented to them, over a year on only the first has led to concrete action being taken (the reorganization of the PCC). The PCS has still not been modified. Besides, this plan has never been tested in real-life conditions (as the last storm occurred in November 2014, before its adoption): it still remains unsure whether the municipality does have the capacity to tackle a high-intensity storm. The most "extreme" scenarios tested as part of the project's hazard analysis show for instance that the spread and volume of the flood would increase by respectively $160 \%$ and $188 \%$ in the event of a hundred-year storm with a 0.6 rise of sea level (Nicolae et al. 2018, Anselme et al. 2017). Just 
as it is necessary to implement a robust prevention policy (the Submersion Risk Prevention Plan for Leucate was approved in January 2017), improving crisis management procedures should also be a priority for the municipality in the years to come.

\section{Conclusion}

The initial objective of the CRISSIS program was to improve both the anticipation of risk and the implementation of adapted responses to better tackle its unpredictability and help with decision-making, in the context of a highly urbanized municipality that is periodically impacted by sea water floods (inundation, barrier overtopping, breaching of barriers). To achieve this, our research focused simultaneously on the natural (hazard), material and social (vulnerability, perception/representations) dimensions of risk. However, the objective was also to engage with local authorities by inviting them to work on the operational aspect of crisis management, which is usually neglected by research programs on flood risk. In this perspective, we worked to improve the various stakeholders' operational response by using crisis exercises to assess the degree to which they had adopted the tools and systems placed at their disposal (PCC, PCS), but also by helping improve these tools and systems using the new findings produced by the program's first three sections.

Overall, this project helped improve our understanding of submersible areas and create maps of critical vulnerability, both material and human. It also revealed the poor social representation of marine submersion risk, as well as a clear lack of awareness of crisis management systems and tools, and of behaviors that should be adopted in the event of a flood. These findings highlight the need for setting up a communication strategy, to raise awareness of risk and inform the population of current alert mechanisms. The crisis exercise conducted in March 2016 with relevant municipal departments showed the importance of creating such exercises working from a realistic scenario, to ensure that all staff in positions of responsibility are aware of procedures, but also to detect any potential gaps in the contents of the PCS. In a context where hazard and vulnerability are bound to become more extreme, this should be a key action in the necessary optimization of crisis management systems and procedures.

\section{Acknowledgements}

We would like to thank the Conseil Supérieur de la Formation et de la Recherche Stratégiques (CSFRS) for funding this research program. Our thanks also go to the municipality of Leucate who volunteered to take part in this program and greatly facilitated our work on the ground.

\section{Funding}

This research work was supported by the French Conseil Supérieur de la Formation et de la Recherche Stratégiques (CSFRS), within the framework of the call for non-thematic projects 2012. The funding body has played no role in the design of the study, the collection, analysis and interpretation of data, or the writing of the manuscript.

\section{Authors' contributions}

BA CRISSIS program manager, manuscript's redaction: intro, conclusion, study area, figures design and layout. PD preparation of crisis simulation exercises, manuscript's redaction: general structure of the paper, intro, conclusion, method, results and discussion (crisis exercises). ALN and SE numerical modeling, manuscript's redaction: method, results and discussion (hazard). SD and MG vulnerability survey, vulnerability index design, manuscript's redaction: method, results and discussion (vulnerability mapping). LG-G and EL survey's conception, survey in the field, statistical treatment, survey's analysis method, results and discussion (risk perceptions and representations). All authors read and approved the final manuscript.

Ethics approval and consent to participate

Not applicable

\section{Consent for publication}

Not applicable

\section{Competing interests}

The authors declare that they have no competing interests.

\section{Publisher's Note}

Springer Nature remains neutral with regard to jurisdictional claims in published maps and institutional affiliations.

\section{Author details}

'Université Paris 1 Panthéon-Sorbonne, 191 rue Saint Jacques, F-75005 Paris, France. ${ }^{2}$ Laboratoire de Géographie Physique, UMR 85911 place Aristide Briand cedex, F-92195 Meudon, France. ${ }^{3}$ Pôle de Recherche pour I'Organisation et la Diffusion de l'Information Géographique, UMR 85862 rue Valette, F-75005 Paris, France. ${ }^{4}$ Université Paul Valéry, 2 rue du Professeur Henri Serre, 34080 Montpellier, France. ${ }^{5}$ UMR GRED - IRD (Gouvernance, Risque, Environnement, Développement), route de Mende, 34199 Montpellier, France. ${ }^{6}$ BRGM, 3 Avenue Claude Guillemin, 45100 Orléans, France. ${ }^{7}$ Centre universitaire de formation et de recherche de Mayotte, Dembéni, Mayotte. ${ }^{8}$ UMR Espace Dev, 500 rue JF Breton cedex 5, 34093 Montpellier, France.

Received: 4 May 2018 Accepted: 3 October 2018

Published online: 29 October 2018

\section{References}

Anneli, J.F. 2006. 2006, the National Incident Management System: A multiagency approach to emergency response in the United States of America. Rev. sci. tech. Off. int. Epiz. 25 (1): 223-231.

Anselme, B., P. Durand, Y.F. Thomas, and A. Nicolae-Lerma. 2011. Storm extreme levels and coastal flood hazards. A parametric approach on the french coast of languedoc (district of Leucate). Comptes Rendus Geosciences 343 (10): 677-690.

Anselme, B., P. Durand, Y.F. Thomas, and A. Nicolae-Lerma. 2017. Coastal flood Hazard. Risk and crisis management: Questions raised by sea level rise? 10-14. New York: International WRCP/IOC Conference, (poster) Columbia University.

Baggio, S., and M.-L. Rouquette. 2006. La représentation sociale de l'inondation : influence croisée de la proximité au risque et de l'importance de l'enjeu. Bulletin de Psychologie 59 (1): 103-117.

Barroca B., Pottier N., Lefort E., 2005, Analyse et évaluation de la vulnérabilité aux inondations du bassin de l'Orge aval. Actes des septièmes rencontres de TheoQuant, Atelier 3 "Risques, vulnérabilité », Besançon, 12p.

Becerra, S. 2012. Vulnérabilité, risques et environnement : l'itinéraire chaotique d'un paradigme sociologique contemporain. VertigO - la revue électronique en sciences de l'environnement [En ligne] 12 (1). URL : http://vertigo.revues.org/ 11988). https://doi.org/10.4000/vertigo.11988.

Booij, N., R.C. Ris, and L.H. Holthuijsen. 1999. A third-generation wave model for coastal regions, part I: Model description and validation. Journal of Geophysical Research 104 (C4): 7649-7666. 
Cariolet, J.-M., S. Suanez, C. Meur-Férec, and A. Postec. 2012, 2012. URL : https:// journals.openedition.org/cybergeo/25077. Cartographie de l'aléa de submersion marine et PPR : éléments de réflexion à partir de l'analyse de la commune de Guissény (Finistère, France). Cybergeo : European Journal of Geography [En ligne], Espace, Société, Territoire, document 586, mis en ligne le 02 février. https://doi.org/10.4000/cybergeo.25077.

Chauveau, E., C. Chadenas, B. Comentale, P. Pottier, A. Blanlœil, T. Feuillet, D. Mercier, L. Pourinet, N. Rollo, I. Tillier, and B. Trouillet. 2011. Xynthia : leçons d'une catastrophe. Cybergeo: European Journal of Geography [En ligne], Environnement, Nature, Paysage, document 538, mis en ligne le 09 juin 2011. URL : https://journals.openedition.org/cybergeo/23763. https://doi.org/ 10.4000/cybergeo.23763.

Church, J.A., P.U. Clark, A. Cazenave, J.M. Gregory, S. Jevrejeva, A. Levermann, M.A. Merrifield, G.A. Milne, R.S. Nerem, P.D. Nunn, A.J. Payne, W.T. Pfeffer, D. Stammer, and A.S. Unnikrishnan. 2013. Sea level change. In Climate change 2013: The physical science basis. Contribution of Working Group I to the Fifth Assessment Report of the Intergovernmental Panel on Climate Change, ed. T. F. Stocker, D. Qin, G.K. Plattner, M. Tignor, S.K. Allen, J. Boschung, A. Nauels, Y. Xia, V. Bex, and P.M. Midgley, 1137-1216. Cambridge: Cambridge University Press. https://doi.org/10.1017/ CBO9781107415324.026.

Creton-Cazenave, L., and V. November. 2017. La gestion de crise à lépreuve de l'exercice. EU SEQUANA, La documentation française, 240:237 p.

D'Ercole, R., and P. Metzger. 2009. La vulnérabilité territoriale : une nouvelle approche des risques en milieu urbain, Cybergeo. European Journal of Geography [En ligne], Dossiers, document 447, mis en ligne le 31 mars 2009, consulté le 14 octobre 2016. URL : https://journals.openedition.org/cybergeo/ 22022. https://doi.org/10.4000/cybergeo.22022.

D'Ercole, R., J.-C. Thouret, O. Dolfus, and J.-P. Asté. 1994. Les vulnérabilités des sociétés et des espaces urbanisés : concepts, typologie, modes d'analyse. Revue de géographie alpine, tome 82, n4: 87-96.

Daniels, R.J., D.F. Kettl, and H. Kunreuther. 2011. On risk an disaster: Lessons from hurricane Katrina, Philadelphia: University of Pensylvania Press, 304 p.

DREAL de bassin Rhône-Méditerranée, 2016, Plan de gestion des risques inondations, bassin Rhône-Méditerranée, 2016-2021, vol 2, 295 p.

Duan, W., B. He, K. Takara, P. Luo, M. Hu, N.E. Alias, and D. Nover. 2015. Changes of precipitation amounts and extremes over Japan between 1901 and 2012 and their connection to climate indices. Clim Dynam 45: 2273-2292.

Duan, W., B. He, K. Takara, P. Luo, M. Hu, N.E. Alias, et al. 2014. Climate change impacts on wave characteristics along the coast of Japan from 1986 to 2012. Journal of Coastal Research 68: 97-104.

Egli, D.S. 2013. Beyond the storms. Strengthning preparedness, Response \& Resilience in the 21 st century. Journal of Strategic Security 6 (2): 32-45.

Flanquart, H. 2014. Perception versus représentation du risque de submersion et autres risques : ce que révèle une querelle sémantique, In Connaissance et compréhension des risques côtiers : aléas, enjeux, représentations, gestion, actes de colloque, 3-4 juillet 2014, Université de Bretagne occidentale, Brest, 353-364.

Gallien, T.W., B.F. Sanders, and R.E. Flick. 2014. Urban coastal flood prediction: Integrating wave overtopping, flood defenses and drainage. Coastal Engineering 91: 18-28. https://doi.org/10.1016/j.coastaleng.2014.04.007.

Genovese, E., S. Hallegatte, and P. Dumas. 2011. Damage assessment from storm surge to coastal cities: Lessons from the Miami area. In Advancing Geoinformation Science for a Changing World. Lecture Notes in Geoinformation and Cartography, (eds). Geertman S., Reinhardt W., Toppen F. vol 1. 21-43. Berlin, Heidelberg: Springer.

Genovese, E., and V. Przyluski. 2013. Storm surge disaster risk management : The Xynthia case study in France. Journal of Risk Research 16(7):825-841.

Goeldner-Gianella L., Chionne D., 2014, Des enquêtes sociales sur les savoirs, les pratiques et les comportements face aux risques littoraux, Colloque international Réduire les risques littoraux et s'adapter au changement climatique, La Rochelle, 2-4 Avril 2014. https://lienss.univ-larochelle.fr/MG/ pdf/actes_colloque_la_rochelle_2-4_avril_2014.pdf.

Guimarães, P.V., L. Farina, E. Toldo Jr., G. Diaz-Hernandez, and E. Akhmatskaya. 2015. Numerical simulation of extreme wave runup during storm events in Tramandaí Beach, Rio Grande do Sul, Brazil. Coastal Engineering 95: 171-180. https://doi.org/10.1016/j.coastaleng.2014.10.008.

Haut Comité Français pour la Défense Civile (HCFDC), 2012, Risques et menaces exceptionnels. Quelle préparation?, Rapport d'activité 2011, 139p.

Hellequin, A.P., C. Meur-Férec, H. Flanquart, and B. Rulleau. 2013. Perceptions du risque de submersion marine par la population locale du littoral languedocien : contribution à l'analyse de la vulnérabilité côtière. Natures Sciences Sociétés 21 (4): 385-399.
Institut National des Hautes Etudes de la Sécurité et de la Justice (INHESJ), 2015. La gestion de crise en Europe. In Vers une coexistence des organisations actuelles basée sur la culture des états membres ou vers une convergence structurelle dans un système européen? Rapport de la 26ème session « Sécurité et Justice » 2014-2015, Groupe de Sécurité stratégique, Paris, 147 p.

Krien N., 2014, Place des risques côtiers dans la représentation du cadre de vie d'individus possédant des enjeux sur des communes "à risque », thèse de I'Université de Bretagne occidentale, 237p.

Lagadec P., 1993, Apprendre à gérer les crises - société vulnérable, acteurs responsables, Editions d'Organisation, 120p.

Lagadec P., 2001, Les exercices de crise : pour des ruptures créatrices, La lettre des cindyniques, $n^{\circ} 34$.

Lagadec, P. 2004. Understanding the French 2003 heat wave experience: Beyond the heat, a multi-layered challenge. Journal of Contengencies and Crisis Management 12 (4): 160-169.

Lagadec, P. 2012. Du risque majeur aux mégachocs. Dossier spécial : la gestion de crise, méthodologies et retours d'expérience, Sécurité et stratégie 10: 50-52.

Lagahé, E., and F. Vinet. 2014. Evaluation de la vulnérabilité des logements face à la submersion sur lîle d'Oléron, Rapport de projet Risks, 103. Île d'Oléron: UMR Liens Université de la Rochelle, PAPI.

Lazure, P., and F. Dumas. 2008. An external-internal mode coupling for a 3D hydrodynamical model for applications at regional scale (MARS). Advances in Water Resources 31: 233-250.

Le Roy, S., R. Pedreros, C. André, F. Paris, S. Lecacheux, F. Marche, and C. Vinchon. 2015. Coastal flooding of urban areas by overtopping: Dynamic modelling application to the Johanna storm (2008) in Gâvres (France). Natural Hazards and Earth System Sciences 15: 2497-2510. https://doi.org/ 10.5194/nhess-15-2497-2015.

Leone F., 2007, Caractérisation des vulnérabilités aux catastrophes «naturelles »: contribution à une évaluation géographique multirisque (mouvements de terrain, séismes, tsunamis, éruptions volcaniques, cyclones) - HDR de I'Université Paul Valéry Montpellier 3, 244 p. + annexes.

Leone F., Asté J-P., Leroi E., 1996, L'évaluation de la vulnérabilité aux mouvements de terrains : pour une meilleure quantification du risque, Revue de géographie alpine, tome 84, n¹, pp. 35-46. https://doi.org/10.3406/rga. 1996.3846. http://www.ano-omiv.cnrs.fr/images/Publications/PDFs/ MasAvignonet/JournalManuscripts/1996-Leone_evaluation.pdf.

Meur-Ferec C., Flanquart H., Hellequin A.P., Rulleau B., 2011, Risk perception, a key component of systemic vulnerability of coastal zones to erosion-submersion. Case study on the French Mediterranean coast. Littoral 2010 - Adapting to Global Change at the Coast: Leadership, Innovation and Investment 2011, Royaume-Uni (2010), 8p.

Nicolae, Lerma A., S. Elineau, T. Bulteau, F. Paris, P. Durand, B. Anselme, and R. Pedreros. 2018. High resolution flood modeling coupling overflowing and overtopping process, framing the hazard based on historical and statistic approach. Natural Hazards and Earth System Sciences 18: 207-229. https://doi. org/10.5194/nhess-18-2017-2018.

Nicolae, Lerma A., S. Elineau, F. Paris, Y. Balouin, S. Lecacheux, P. Durand, B. Anselme, E. Longepe, S. Defossez, and Gianella L. Goeldner. 2015. Modélisation numérique de l'aléa de submersion appliquée à l'élaboration des plans d'évacuation et à la gestion de crise, exemple de la commune de Leucate. Ferrare: Paralia, In: Actes 3rd Coastal And Maritime Mediterranean Conference.

Pont C., 2015, Aborder et caractériser le risque de submersion marine sur les littoraux sableux méditerranéens : I'exemple de la commune de Leucate, mémoire de master, université Paris 1 Panthéon Sorbonne, 150 p.

Reghezza Zitt, M., and S. Rufat. 2015. Résiliences. Sociétés et territoires face à l'incertitude, aux risques et aux catastrophes, 226. London: ISTE Editions.

Ruin I., 2010, Conduite à contre-courant et crues rapides, le conflit du quotidien et de l'exceptionnel, Annales de la Géographie, v4, n674, p. 419-432.

Samuels, P., Huntington S., Allsop W., Harrop W., 2008, Flood risk management : Research and Practice. Proceedings of the European conference on flood risk management research into practice (Floodrisk 2008), Oxford, extended abstracts volume, $332 \mathrm{p}$.

Slangen, A.B.A., M. Carson, C.A. Katsman, R.S.W. van de Wal, A. Köhl, L.L.A. Vermeersen, and D. Stammer. 2014. Projecting twenty-first century regional sea-level changes. Climatic Change 124 (1): 317-332.

Sorensen, C., M. Jebens, and T. Piontkowitz. 2017. Danish risk management plans of the EU flood directive. La Houille Blanche, $n^{\circ}$ 4: 31-39.

Stern, E. 2014. Designing Crisis Management Training and Exercises for Strategic Leaders. A Swedish and United States Collaborative Project., 112. Stockholm: Swedish National Defense College, Elanders Sverige AB. 
Thouret, J.-C., and R. D'Ercole. 1996. Vulnérabilité aux risques naturels en milieu urbain : effets, facteurs et réponses sociales. Cahiers des sciences humaines, ORSTOM 32 (2): 407-422.

Ullmann, A. 2009. Changement climatique et évolution des tempêtes dans le Golfe du Lion : approche par intégration d'échelles spatio-temporelles. Cybergeo : European Journal of Geography [En ligne], Environnement, Nature, Paysage, document 441, mis en ligne le 18 mars 2009, consulté le 25 janvier 2017. URL https://journals.openedition.org/cybergeo/22013. https://doi.org/10.4000/ cybergeo.22013.

Vinchon C., Baron-Yelles N, Berthelier E., Hérivaux C., Lecacheux S., Meur-Ferec C., Pedreros R., Rey-Valette H., Rulleau B., 2011, MISEEVA: Set up of a transdisciplinary approach to assess vulnerability of the coastal zone to marine inundation at regional and local scale, within a global change context, Littoral 2010 - Adapting to Global Change at the Coast: Leadership, Innovation, and Investment, London 21-23 September 2010, 10p.

Wassner T.S., Sauvagnargues, P.A. Ayral, F. Tena-Chollet, N. Frealle, 2016. Retour sur l'exercice de simulation de crise au sein du simulateur de l'école des mines d'Alès, rapport WP4 - D4 - 3a, projet ANR SPICy "Système de prévision des inondations côtières et fluviales en contexte cyclonique", 142 p.

Yates-Michelin M., Le Cozannet G., Balouin Y., 2011, Etat des connaissances sur les effets potentiels du changement climatique sur les aléas côtiers en région Lanquedoc-Roussillon, rapport final BRGM/RP 58 872- FR, 83p., 26 III., 2 annexes.

Zijlema M., Stelling G., Smit P., 2011, "SWASH: An operational public domain code for simulating wave fields and rapidly varied flows in coastal waters".

\section{Submit your manuscript to a SpringerOpen ${ }^{\circ}$ journal and benefit from:}

- Convenient online submission

- Rigorous peer review

- Open access: articles freely available online

- High visibility within the field

Retaining the copyright to your article

Submit your next manuscript at $\boldsymbol{\nabla}$ springeropen.com 